Gut, 1971, 12, 179-183

\title{
Protein loss and cell loss from the small-intestinal mucosa $^{1}$
}

\author{
L. R. DA COSTA, ${ }^{2}$ D. N. CROFT, AND B. CREAMER \\ From the Gastrointestinal Laboratory, St Thomas' Hospital, London SE1
}

SUMMARY Total protein and deoxyribonucleic acid (DNA) were measured in small-intestinal washings from rats with normal and high rates of DNA (or cell) loss. There was a significant relationship between the loss of these two substances. Preparations of isolated viable epithelial cells contained much less protein in relation to DNA than did the intestinal washings. It was calculated that only 8 to $15 \%$ of the protein lost by washing the rat small intestine arose from the intracellular protein of exfoliated epithelial cells. The rest was derived from extracellular sources.

Protein and DNA loss from small-bowel mucosa was measured in six patients. The ratio of protein to DNA was similar to that found in the rats. The mean protein loss from $5 \mathrm{~cm}$ of human upper small intestine was $956 \mu \mathrm{g}$ per min or $1.4 \mathrm{~g}$ per 24 hours. By calculation, total protein loss from the whole small intestine of man was about $84 \mathrm{~g}$ per day, about $10 \mathrm{~g}$ coming from within exfoliated cells and the rest arising from extracellular sources. The normal intestine must reabsorb most of this material.

The small bowel handles much more protein than the quantity taken by mouth. For instance, in the $\mathrm{dog}$ and rat, Nasset and $\mathrm{Ju}$ (1961) found that ingested protein was swamped four- or fivefold by endogenous protein. In man it has been estimated that some 45-140 grams of protein are lost into the gut per 24 hours (Spencer, 1960; Wilson, 1962). This large quantity of protein is derived in part from gastrointestinal secretion from saliva, stomach, pancreas, and bile (Spencer, 1960; Nasset, 1964). It has been suggested that exfoliated epithelial cells may be another significant source of endogenous protein (Nasset, 1964; Jefferies, Holman, and Sleisenger, 1962). Wilson (1962) claimed that small intestinal cells in man may account for $25 \mathrm{~g}$ of protein per 24 hours and Nasset (1965) calculated that the amount could be as much as $90 \mathrm{~g}$.

The small-intestinal mucosa is dynamically the most active epithelial surface in the body, in man losing some 20-50 million cells per minute (Croft, Loehry, Taylor, and Cole, 1968b). If significant amounts of protein are lost in exfoliated cells the small bowel is an important organ to study this phenomenon. We have done so by measuring, in intestinal washings from rat and man, deoxyribo-

'A paper presented to the British Society of Gastroenterology on 25 April 1969.

'Present address: Department of Medicine, University of the West Indies, Kingston, Jamaica.

Received for publication 21 October 1970. nucleic acid (DNA) loss (as an estimate of cell loss), and protein loss. To assess the contribution of intracellular protein intestinal epithelial cells were isolated and their DNA and protein content was measured.

\section{Materials and Methods}

\section{BIOCHEMICAL METHODS}

Deoxyribonucleic acid was measured by a modified diphenylamine reaction and the values were expressed in ng atoms DNA-P (Croft and Lubran, 1965).

Protein was measured by the Lowry method (Papadopoulos, Hess, O'Doherty, and McLane, 1959), the standard curve being made with human serum protein. Aliquots of the specimens were concentrated by dialysis. The final technique was highly sensitive and reproducible (da Costa, 1970).

WASHINGS OF RAT SMALL INTESTINE

The details of this technique have already been described (Loehry, Croft, Singh, and Creamer. 1969). Male albino rats weighing $350-450 \mathrm{~g}$ were starved for 24 hours and then anaesthetized. Two pieces of polyvinylchloride tubing were tied respectively into the jejunum at the duodenojejunal flexure and at the terminal ileum. Normal saline was infused via the jejunal tube at measured rates for two to four hours. Fluid was collected from the ileal tube. The rats were killed at the end of the experi- 
ments. In 11 normal rats the small intestine was washed with saline at a constant rate of $250 \mathrm{ml} / \mathrm{h}$ for one to five hours. A total of 29 hourly specimens were obtained and DNA and protein measured in them. Each specimen was tested for bleeding by Haemocombostix and was negative. Intravenous ${ }^{51} \mathrm{Cr}$-tagged red cells have previously been shown not to appear in the specimen (Loehry et al, 1969). ${ }^{51} \mathrm{CrCl}_{3}$-labelled protein loss in three rats washed at $250 \mathrm{ml}$ per hour indicated a loss of $5.1 \mathrm{mg}$ of albumin per hour which compares favourably with the value of 3.6-6.0 mg per hour found by other physiological methods (Katz, Rosenfield, and Sellers, 1961; Wetterfors, Gullberg, Liljedahl, Plantin, Birke, and Olhagen, 1960). Thus at this rate of perfusion there was no evidence that trauma occurred to the mucosa.

In 10 normal rats the rate of washing with saline was altered so that nine specimens were obtained at $150 \mathrm{ml}$ per hour, eight at $250 \mathrm{ml}$ per hour, 10 at $500 \mathrm{ml}$ per hour, and eight at $1,000 \mathrm{ml}$ per hour. There was histological evidence of minor trauma to the mucosa only at the fastest washing rate.

Small bowel washings were performed at a constant rate of $250 \mathrm{ml}$ per hour in 10 rats with high turnover mucosa. High turnover was induced in the mucosa of these rats by infestation with the nematode Nippostrongylus brasiliensis which has been shown to cause a high turnover and loss of intestinal epithelial cells (Symons and Fairbairn, 1962; Loehry et al, 1969). Twenty-seven specimens were analysed for DNA and protein. The results were compared with the 29 specimens from rats with normal small bowel washed at $250 \mathrm{ml}$ per hour.

\section{SUSPENSION OF VIABLE INTESTINAL}

ABSORPTIVE CELLS

In order to measure the intracellular protein content of intestinal epithelial cells a preparation of isolated epithelial cells was made using pronase to disperse the cells from the mucosa (Harrier, Stern, and Reilly, 1964; Croft and Ingelfinger, 1969). Pronase solution $(0.25 \%$ in phosphate-buffered saline) was injected into the small intestine lumen of anaesthetized rats and left for 15 minutes at $37^{\circ} \mathrm{C}$. After removal the cloudy suspension of cells was filtered through 100 mesh tantalum gauze and washed twice. Examination of the cells by the dye exclusion technique using erythrosin B showed that they were $85-95 \%$ viable (Phillips and Terryberry, 1957). Cytology and electron microscopic study confirmed that they were mainly absorptive cells with brush borders (Pink, Croft, and Creamer, 1970) and histology of the mucosa showed that only surface epithelial cells had been removed. The concentration of cells in the preparations was varied by altering the length of time during which pronase was in contact with mucosa and by varying the degree of agitation of the gut. Fourteen cell suspensions were prepared and analysed for DNA and protein.

\section{SMALL-INTESTINAL WASHINGS IN MAN}

Small-bowel washings were performed on six patients at the time of secretin tests of pancreatic function by a method previously described (Croft et al, 1968b). Patients 1 to 4 had no clinical or other evidence of small bowel disease, patient 5 had the coeliac syndrome with a flat jejunal mucosa, and patient 6 had Crohn's disease of the ileum but normal upper small-intestinal biopsy. The method measures cell loss from a $5 \mathrm{~cm}$ segment of upper small lintestine without significant contamination by secretions from the stomach, biliary tree, or pancreas. Rates of DNA loss and protein loss were calculated after correction for loss of the unabsorbable marker polyethylene glycol (PEG).

\section{Results}

INTESTINAL W ASHINGS

The DNA and protein content of intestinal washings from 10 rats with a normal small intestine increased as the rate of washing increased (Fig. 1). There was a highly significant relationship $(t=4.016, P<0.001)$ between the loss of these two substances as calculated from the regression line for DNA (axis y) on protein (axis $x$ ). (The cause of the increased loss with increasing rates of washing has been shown to be due to improved cleaning of the gut at the faster rates, rather than trauma (P. K. Cotton, personal communication).)

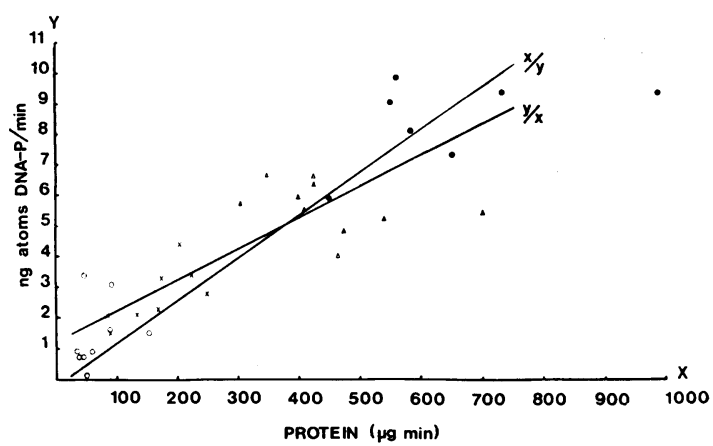

FIG. 1. DNA loss and protein loss from normal rat small bowel washed at different rates. $\bigcirc=150 \mathrm{ml} /$ hour, $\times=250 \mathrm{ml} /$ hour, $\triangle=500 \mathrm{ml} /$ hour, $\bigcirc=1,000 \mathrm{ml} /$ hour. Two regression lines $(x / y$ and $y / x)$ are plotted. There is a significant relation between DNA (or cell) loss and protein loss $(y / x ; t=4.016, \mathrm{P}<0.001)$. 
At a constant washing rate of $250 \mathrm{ml}$ per hour, there was significantly more DNA $(P<0.01)$ and protein $(P<0.01)$ in specimens from the infected rats than in those with a normal small-intestinal mucosa (Table I). The ratios of protein/DNA were not significantly different between the two groups.

There was a significant correlation between loss of DNA and protein in the normal rats washed at $250 \mathrm{ml}$ per hour $(\mathrm{r}=+0.63, \mathrm{P}=<0.001)$. The pooled data for normal and abnormal rats washed

\begin{tabular}{|c|c|c|}
\hline & \multicolumn{2}{|l|}{ Intestinal Mucosa } \\
\hline & Normal (11 rats) & High Turnover (10 rats) \\
\hline $\begin{array}{l}\text { DNA loss rate } \\
\text { (ng atoms DNA-P per }\end{array}$ & $\begin{array}{l}2.9 \mathrm{SE} 0.26(\mathrm{n}=29) \\
\min )\end{array}$ & $7.7 \mathrm{SE} 0.55^{1}(n=27)$ \\
\hline $\begin{array}{l}\text { Protein loss rate } \\
\text { ( } \mu \text { g per min) } \\
\text { Ratio protein loss/ } \\
\text { DNA loss }\end{array}$ & $\begin{array}{l}159 \text { SE } 14(n=29) \\
55 \text { (range } 23-200)\end{array}$ & $\begin{array}{l}554 \mathrm{SE} 41^{1}(\mathrm{n}=32) \\
72 \text { (range } 26-138)\end{array}$ \\
\hline
\end{tabular}

Table I Protein and DNA loss in small-intestinal washings from rats washed at a constant rate of $250 \mathrm{ml}$ per minute

${ }^{1} \mathbf{P}<0.01$

at a constant rate are shown in Figure 2. Regression analysis for DNA (axis $y$ ) on protein (axis $x$ ) proved that this relationship was also significant $(t=3 \cdot 0$, $P<0.01$ ). There was no significant difference between the calculated regression line for DNA loss

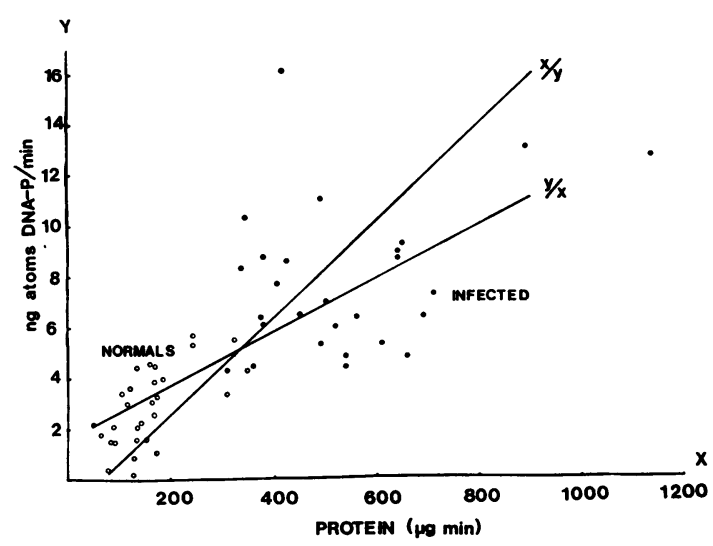

FIG. 2. Plot of DNA loss (y axis) against protein loss ( $x$ axis) for small bowel washed at a constant rate of $250 \mathrm{ml}$ per hour. $\bigcirc=$ normal rats, $\bigcirc=$ rats with high turnover mucosa. Regression lines of $x / y$ and $y / x$ are plotted. There is a significant relationship between $D N A$ (or cell) loss and protein loss $(y / x: t=3 \cdot 0, \mathrm{P}<0 \cdot 01)$. on protein loss $(y / x)$ for (1) constant rate of washing $(250 \mathrm{ml} / \mathrm{hr}$ ) of normal rats; (2) different rates of washing of normal rats; or (3) constant rate of

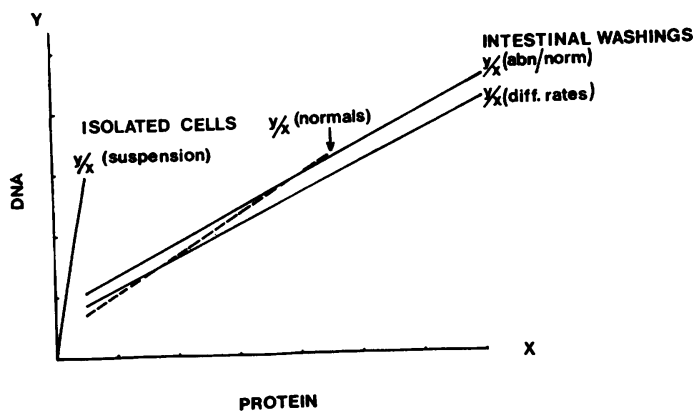

FIG. 3. Regression lines for DNA against protein of the intestinal washing experiments on right and for isolated rat intestinal cells on left. The broken line is the regression line for rats washed at $250 \mathrm{ml} / \mathrm{hour}(r=$ $+0.63, \mathrm{P}<0.001)$. The upper solid line on the right is $y / x$ regression line from Fig. 2 and the lower one is $y / x$ plot from Figure 1. On the left is the regression line on $y / x$ for isolated cells (Fig. 4). There is considerably more protein in relation to DNA in intestinal washings than in isolated epithelial cells.

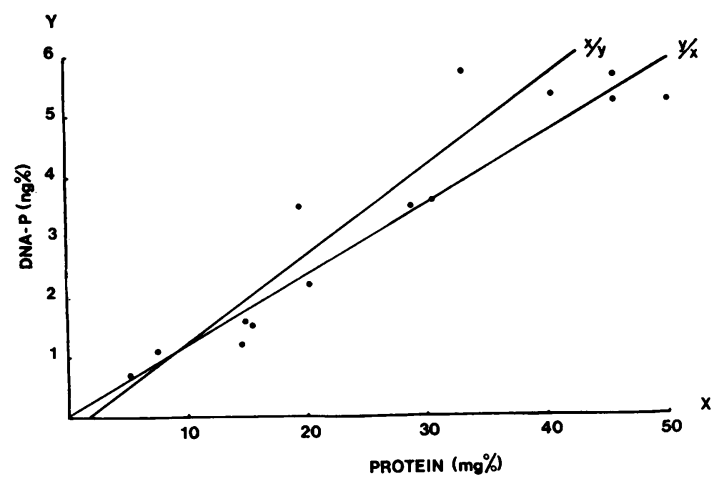

FIG. 4. DNA and protein concentration of 14 specimens of isolated intestinal cells. Regression lines ( $x / y$ and $y / x)$ are plotted. There is a significant correlation between DNA and protein concentration $(\mathrm{P}<0.001)$.

washing $(250 \mathrm{ml} / \mathrm{hr})$ of normal and infected rats (Fig. 3).

ISOLATED INTESTINAL CELLS

There was a highly significant $(P<0.001)$ relationship between the DNA and protein content of the suspensions of isolated epithelial cells (Fig. 4). The ratio of protein to DNA in the specimen was 8.18 


\begin{tabular}{|c|c|c|c|c|c|c|c|}
\hline \multirow[t]{2}{*}{ Patient } & \multirow[t]{2}{*}{ Age } & \multirow[t]{2}{*}{ Sex } & \multirow[t]{2}{*}{ Diagnosis } & \multicolumn{2}{|c|}{ Washing } & \multirow{2}{*}{$\begin{array}{l}\text { DNA Loss Rate } \\
\text { (ng atoms DNA-P per min) }\end{array}$} & \multirow{2}{*}{ 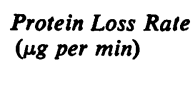 } \\
\hline & & & & No. & Rate $(\mathrm{ml} / \mathrm{hr})$ & & \\
\hline 1 & 52 & $\mathbf{M}$ & $\begin{array}{l}\text { Duodenal ulcer, vagotomy and } \\
\text { pyloroplasty }\end{array}$ & I & $18 \cdot 5$ & $\left.{ }^{7 \cdot 8}\right\} 6.0$ & $1,274\}_{1,030}$ \\
\hline 2 & 61 & $\mathbf{F}$ & Sjögren's syndrome & $\begin{array}{l}\text { II } \\
\text { I }\end{array}$ & $\begin{array}{l}18 \cdot 5 \\
14 \cdot 7\end{array}$ & $\begin{array}{l}4 \cdot 3 \\
7 \cdot 6\end{array}$ & $\begin{array}{l}787 \\
585\end{array}$ \\
\hline & & & & II & $15 \cdot 2$ & $6 \cdot 3 \int^{0}$ & 157\{ \\
\hline 3 & 60 & $\mathbf{M}$ & Carcinoma pancreas & I & $16 \cdot \overline{1}$ & $9 \cdot 9\} 11 \cdot 2$ & $563\}$ \\
\hline 4 & 56 & $\mathbf{M}$ & Chronic pancreatitis & II & $\begin{array}{l}15 \cdot 8 \\
17 \cdot 8\end{array}$ & 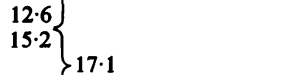 & $\begin{array}{r}479 \\
1,221 \\
2,027\end{array}$ \\
\hline 5 & 60 & $\mathbf{F}$ & Coeliac syndrome & $\begin{array}{l}\text { II } \\
\text { I }\end{array}$ & $\begin{array}{l}16 \cdot 2 \\
12 \cdot 2\end{array}$ & $\begin{array}{l}19 \cdot 0 \\
19.9 \\
21 \cdot 2\end{array}$ & $\left.\begin{array}{r}2,924 \\
182\end{array}\right\}$ \\
\hline 6 & 60 & $\mathbf{M}$ & Crohn's disease & II & $\begin{array}{l}17 \cdot 2 \\
13 \cdot 1\end{array}$ & $\begin{array}{l}22 \cdot 6 \\
36 \cdot 6 \\
30 \cdot 7\end{array}$ & $\left.\begin{array}{l}1,207 \\
1,394\end{array}\right\}$ \\
\hline $\begin{array}{l}\text { Mean } \\
\text { SD }\end{array}$ & & & & II & $17 \cdot 8$ & 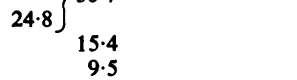 & $803 \int_{\begin{array}{l}956 \\
574\end{array}}$ \\
\hline
\end{tabular}

Table II DNA and protein loss rates from six patients

$(\mathrm{SE}=0.44, \mathrm{n}=14)$ which was much lower than that for the washings (Table I). This meant that there was considerably less protein in relation to DNA in the isolated cell preparation than in the washings (Fig. 3).

Most of the protein in the washings came from sources other than cells. The ratio of the regression coefficients for the isolated cell and the intestinal washings performed at different rates indicated that only $8 \cdot 4-14 \cdot 6 \%$ of the protein in the washings was contributed by intracellular protein. When the calculation was performed using the pooled data from normal and abnormal rats washed at a constant rate, the percentage of protein contributed by cells was calculated to be $9 \cdot 4-11 \cdot 1 \%$, which was within the same range.

\section{HUMAN DATA}

The results of the observations in man are recorded in Table II.

\section{Discussion}

Using two experimental models in rats a highly significant relationship was found between the loss of total protein from small intestinal mucosa and the loss of DNA (or cells). Only $8-15 \%$ of the protein in intestinal washings arose from intracellular protein; $85-92 \%$ was extracellular protein. The extracellular protein could have come from a number of sources, such as plasma, mucoproteins, and interstitial fluid. One interpretation of the data is that extracellular protein is lost with the epithelial cell as it exfoliates, perhaps through the hole left by the extruded cell. If so, cell loss would explain protein-losing enteropathy in the active coeliac syndrome, for in this condition there is a higher than normal loss of epithelial cells (Croft, Loehry, and Creamer, 1968a).

Our data for protein loss from the small bowel mucosa of man is derived from six subjects (Table II). The small bowel DNA-loss rates of patients 1-4 were within the normal range for patients with normal small-intestinal mucosa (Croft et al, 1968b). None of these patients had evidence of mucosal disease of the small intestine. Two patients (5 and 6) had small bowel disease and the rates of DNA loss of both were above the normal range. Patient 5 had the coeliac syndrome and was losing weight, a clinical situation previously reported to be associated with high DNA loss (Croft et al, 1968a). The other patient had Crohn's disease involving the terminal small bowel. The mean small bowel DNA-loss rates of the six patients was $15.4(\mathrm{SD}=9.5) \mathrm{ng}$ atoms DNA-P per min which was within the normal range. The ratio of protein to DNA loss was $62 \cdot 1$, a value in the same range as that found in the rat intestinal washings (Table I). The mean protein loss for the six subjects was $956(\mathrm{SD}=574) \mu \mathrm{g}$ per minute. If one assumes that this rate was constant throughout the 24 hours, our measured value represents a loss from $5 \mathrm{~cm}$ of jejunum of $1.4 \mathrm{~g}$ protein per 24 hours.

Because of the small number of studies we do not claim that the human data reflect the physiological situation, but we do believe that it gives a figure for the order of magnitude of protein loss from human small bowel mucosa. Our value of $1.4 \mathrm{~g}$ per 24 hours was the loss from only $5 \mathrm{~cm}$ of small intestine. The small bowel is some three hundred centimetres long 
and, if protein loss occurs at the same rate throughout its length, $84 \mathrm{~g}$ would be lost per 24 hours, about $10 \mathrm{~g}$ arising from intracellular protein of exfoliated cells. These figures may be overestimated, as protein loss is likely to be less in the ileum but they are of the same order as, or less than, the values discussed by others (Spencer, 1960; Wilson, 1962; Nasset, 1964 and 1965). We conclude that the amount of protein lost from human small bowel mucosa per 24 hours is substantial and that it is related to the rate of loss of epithelial cells. Presumably the normal intestine digests and absorbs this protein. Irretrievable loss of protein from the body will occur when the intestine is diseased, has a high rate of cell and protein loss, and is also less able to reabsorb, as in the coeliac syndrome.

The work was supported by a British Commonwealth fellowship to L. R. Da Costa, and by a grant from St Thomas's Endowment Fund. We thank Miss Judy Cole for biochemical help and Dr Z. Roth of the Department of Social Medicine at St Thomas's Hospital for statistical advice.

Requests for reprints should be sent to $D$. N. Croft.

\section{References}

Costa, L. R. da (1970). Protein and the Small intestine. MD Thesis, London.

Croft, D. N., and Ingelfinger, F. J. (1969). Isolated gastric parietal cells: oxygen consumption, electrolyte content and intracellular pH. Clin. Sci., 37, 491-501.
Croft, D. N., Loehry, C. A., and Creamer, B. (1968a). Small-bowel cell-loss and weight-loss in the coeliac syndrome. Lancet, 2, 68-70.

Croft, D. N., Loehry, C. A., Taylor, J. F. N., and Cole, J. (1968b). DNA and cell loss from normal small-intestinal mucosa. Lancet, 2, 70-73.

Croft, D. N., and Lubran, M. (1965). The estimation of deoxyribonucleic acid in the presence of sialic acid; application to analysis of human gastric washings. Biochem. J., 95, 612-620.

Harrier, D. S., Stern, B. K., and Reilly, R. W. (1964). Removal and dissociation of epithelial cells from the rodent gastrointestinal tract. Nature (Lond.), 203, 319-320.

Jefferies, G. H., Holman, H. R., and Sleisenger, M. H. (1962). Plasma proteins and the gastrointestinal tract. New Engl.J. Med., 266, 652-660.

Katz, J., Rosenfeld, S., and Sellers, A. L. (1961). Sites of plasma albumin catabolism in the rat. Amer. J. Physiol., 200, 13011306.

Loehry, C. A., Croft, D. N., Singh, A. K., and Creamer, B. (1969). Cell turnover in the rat small intestinal mucosa : an appraisal of cell loss. Gut, 10, 13-18.

Nasset, E. S. (1964). The role of the digestive tract in protein metabolism. Amer. J. dig. Dis., 9, 175-190.

Nasset, E. S. (1965). Role of the digestive system in protein metabolism. Fed. Proc., 24 ii, 953-958.

Nasset, E. S., and Ju, J. S. (1961). Mixture of endogenous and exogenous protein in the alimentary tract. J. Nutr., 74, 461-465.

Papadopoulos, N. M., Hess, W. C., O'Doherty, D., and McLane, J. E. (1959). A procedure for the determination of cerebrospinal fluid total protein and gamma globulin in neurologic disorders. Clin. Chem., 5, 569-574.

Phillips, H. J., and Terryberry, J. E. (1957). Counting actively metabolising tissue cultured cells. Exp. Cell Res., 13, 341-347.

Pink, I. J., Croft, D. N., and Creamer, B. (1970). Cell loss from small intestinal mucosa: a morphological study. Gut, 11, 217-222.

Spencer, R. P. (1960). In The Intestinal Tract, pp. 309-330. Thomas, Springfield, Ill.

Symons, L. E. A, and Fairbairn, D. (1962). Pathology, absorption, transport and activity of digestive enzymes in rat jejunum parasitized by the nematode Nippostrongylus braziliensis. Fed. Proc., 21, 913-918.

Wetterfors, J., Gullberg, R., Liljedahl, S. O., Plantin, L. O., Birke, G., and Olhagen, B. (1960). Role of the stomach and small intestine in albumin breakdown, Acta. med. scand., 168, 347-363.

Wilson, T. H. (1962). Intestinal Absorption, p. 111. Saunders, Philadelphia. 